\title{
Improving Durability of Electric Motor Bearing Shields Using Combined Technology
}

\author{
Yu.A. Kuznetsov ${ }^{1}$, I.N. Kravchenko ${ }^{2 *}$, A.L. Galinovsky ${ }^{3}$, D.D. Yakovlev ${ }^{1}$, I.D. Makarov ${ }^{1}$ \\ ${ }^{1}$ Orel State Agrarian University named after N.V. Parakhin, 69 Generala Rodina St., 302019, Orel, Russia; \\ ${ }^{2}$ Russian Timiryazev State Agrarian University, 49 Timiryazevskaya, Moscow, 127550, Russia; \\ ${ }^{3}$ Bauman Moscow State Technical University, building 1, 5, Baumanskaya 2-ya, Moscow, 105005, Russia \\ * Corresponding author. Tel.: +7 49997601 70. E-mail address: kravchenko-in71@yandex.ru
}

\begin{abstract}
A combined technology for increasing the durability of bearing holes of electric motor bearing shields made of aluminum alloys is presented. The assessment of the wear resistance of the formed coatings is given.
\end{abstract}

\section{Keywords}

Gas-dynamic spraying; micro-arc oxidation; technology; electric motor.

(C) Yu.A. Kuznetsov, I.N. Kravchenko, A.L. Galinovsky, D.D. Yakovlev, I.D. Makarov, 2020

\section{Formulation of the problem}

For most electric motors, the bearing assembly is the second most important source of failure (after the winding). One of the main reasons for the failure of the unit under consideration is the wear of the bearing seat of the end shield (Fig. 1), which occurs due to fretting corrosion and the subsequent rotation of the bearing rings.

At present, bearing seats of electric motor shields are repaired with polymer materials, by the methods of thermal spraying, and by pressing in repair bushings.

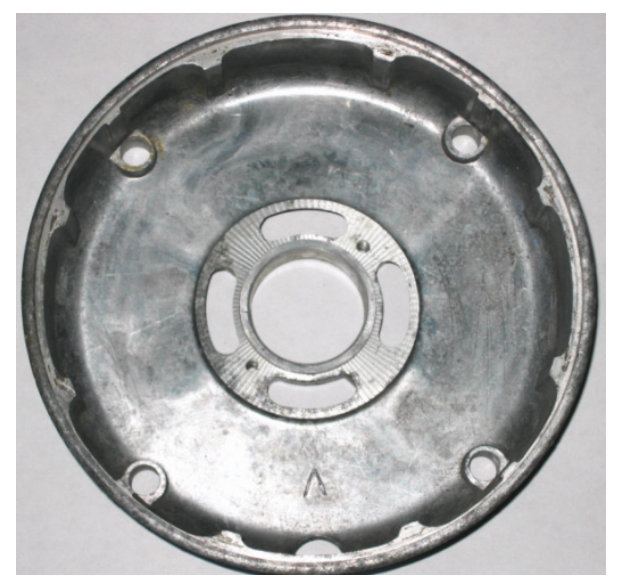

Fig. 1. General view of the end shield of the electric motor
The Obninsk powder spraying center has developed a fundamentally new method for restoring these parts - supersonic gas-dynamic spraying (GDS) [1-4], the main advantages of which are environmental friendliness, simplicity, the possibility of forming coatings up to several millimeters thick, high adhesion of sprayed coatings to the base (40-80 MPa).

However, since the powder mixtures based on soft metals (aluminum, copper) are used in GDS, the resulting coatings have low hardness and wear resistance $[5,6]$. As a result of this, the resource of the parts rebuilt by the GDS, as a rule, is lower than the resource of new parts. To eliminate these shortcomings, a combined technology for restoring and hardening this group of parts is proposed. Its essence lies in the fact that, first, a worn-out end-shield bore is restored with a supersonic GDS, and then, in order to improve antiwear properties, it is strengthened by micro-arc oxidation (MAO) [7-11].

\section{Materials and methods}

"Cold" gas-dynamic spraying was carried out on a DIMET-403 installation (Fig. 2). For spraying, A-80-13 aluminum powder was used.

Reagents used for MAO were potassium hydroxide GOST 24363 (rev.1); liquid glass GOST 130078 with module $m=3.0$ and density $\rho=$ $=1.47 \cdot 10^{3} \mathrm{~kg} / \mathrm{m}^{3}$. The formation of coatings was 
carried out in an electrolyte of the $\mathrm{KOH}-\mathrm{Na}_{2} \mathrm{SiO}_{3}$ type at the following modes: $D_{\mathrm{c}}=18 \mathrm{~A} / \mathrm{dm}^{2} ; t=120 \mathrm{~min}$; electrolyte: $C_{\mathrm{KOH}}=1 \mathrm{~g} / 1, C_{\mathrm{Na}_{2} \mathrm{SiO}_{3}}=8 \mathrm{~g} / 1$.

The samples were oxidized using the MAO setup shown in Fig. 3.

For testing, we used AK12, AK7ch, G-AlSi12 aluminum alloys [12-14], which can serve as a material for the manufacture of bearing shields for electric motors. The adhesion of the sprayed layer was determined by the pin method, the essence of which is to determine the value of the breaking force when the pin is pulled out in the direction normal to its end surface, on which the coating is applied.

The sample consists of a pin (Fig. 4a) and a washer (Fig. $4 b$ ) with a gripping device in the form of a hole for splitting, providing interconnection with a coating layer when sprayed together. The cylindrical surface of the mating of parts with a diameter of $4 \mathrm{~mm}$ was carried out on a sliding fit. The sample was made from an aluminum alloy.

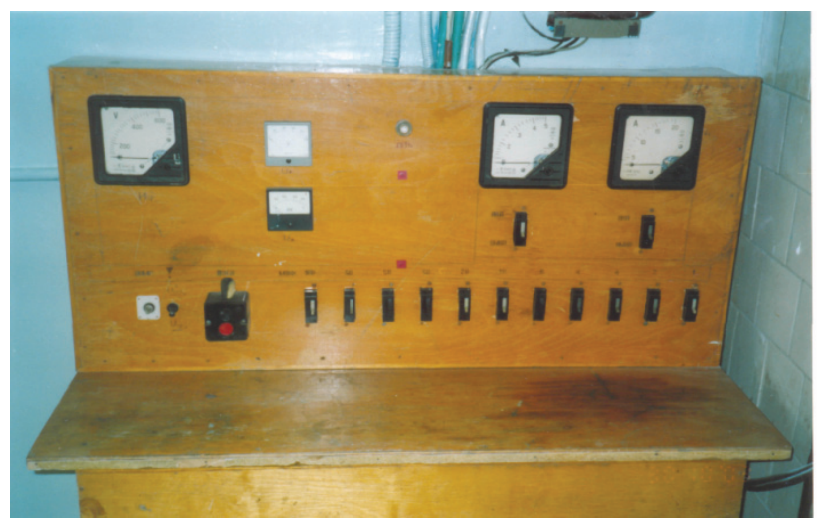

a)

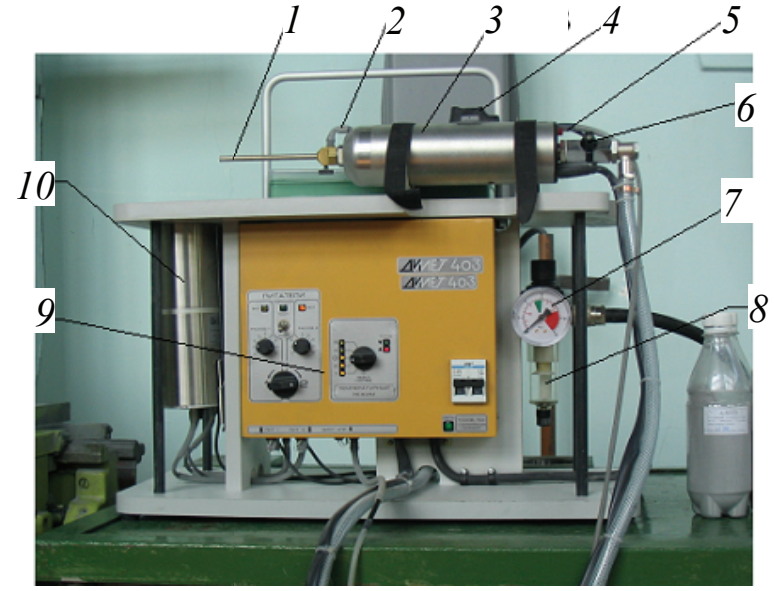

Fig. 2. DIMET-403 setup:

1 - nozzle; 2 - silicone adapter; 3 - sprayer;

4 - powder feed button; 5 - powder feed tube;

6 - pneumatic crane; 7 - manometer; 8 - filter regulator;

9 - monitor and control unit; 10 - feeder

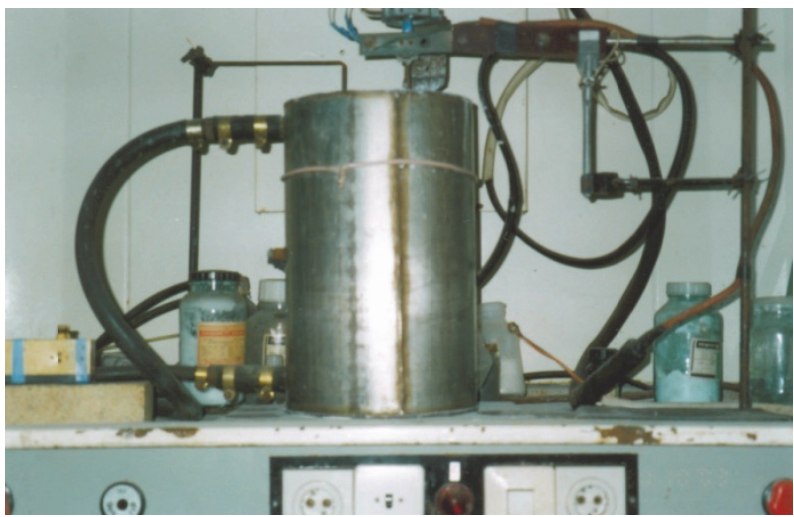

b)

Fig. 3. General view of the laboratory setup for MAO: $a$ - power supply and control unit; $b$ - electrolytic bath

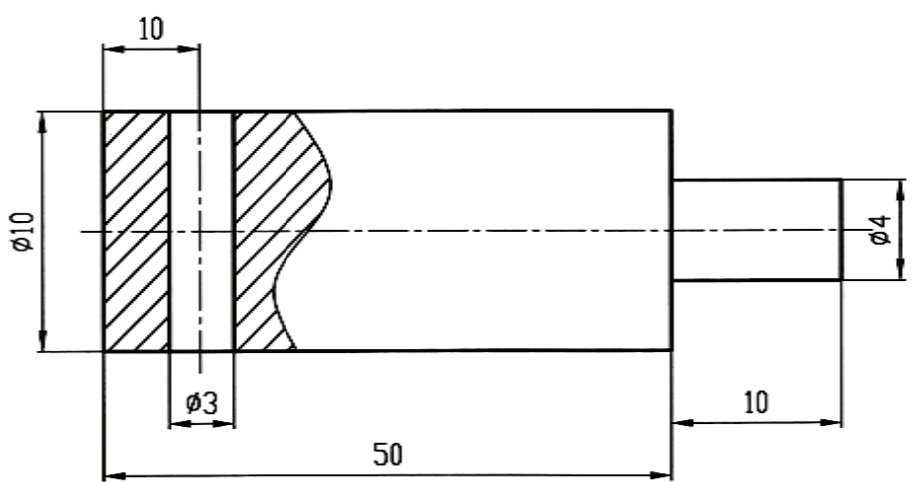

a)

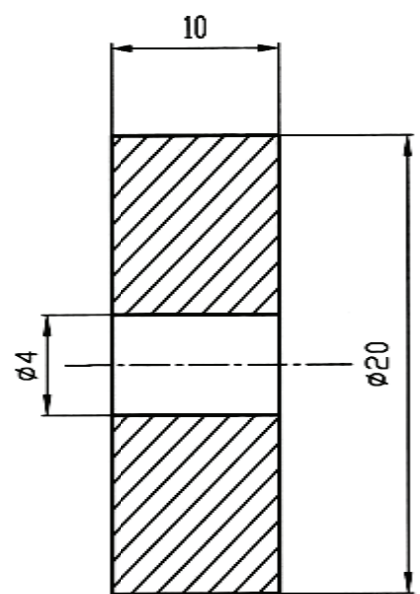

b)

Fig. 4. Sample for determining the adhesion of the coating and the treated surface: $a-$ pin, $b-$ washer 


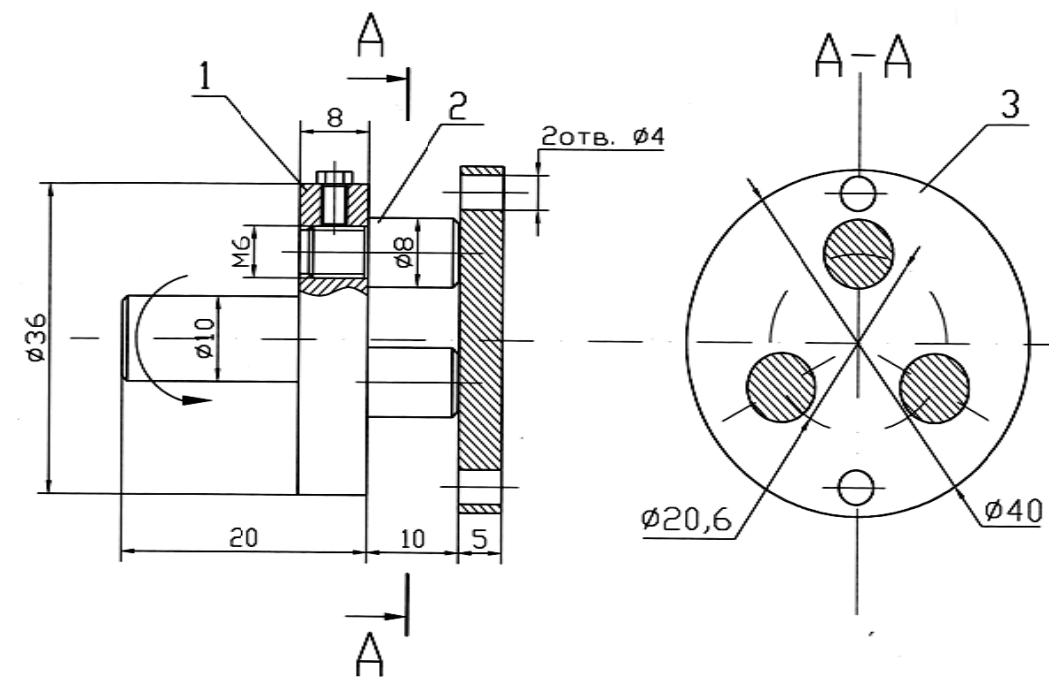

Fig. 5. Wear test samples:

1 - mandrel for upper samples; 2 - upper sample; 3 - bottom sample

The pin assembly with the washer was installed in the device to fix the sample, and grinding of the working surface was carried out. The coating was sprayed onto the working surface of the sample with its uniform movement under the condition:

$$
s=(0.77-1) d,
$$

where $s$ is sprayed layer thickness, $\mathrm{mm} ; d$ is pin diameter, $\mathrm{mm}$.

The sample was tested on a universal tensile testing machine PM-1000.

The tear-off stress of the coating is determined for each sample by the formula [15]:

$$
P_{\mathrm{a}}=\frac{4 F}{3.14 d^{2}},
$$

where $P_{\mathrm{a}}$ is tear-off stress when determining the value of adhesion, $\mathrm{MPa} ; F$ is breaking force, $\mathrm{N} ; d$ is pin diameter, $\mathrm{mm}$.

The comparative wear resistance of the surfaces of the samples was investigated under conditions of boundary lubrication according to GOST 23.224-86 on an MTU-01 friction machine (TU 4271-001-290346002004). In this case, the lower sample (Fig. 5) was made of an aluminum alloy with subsequent spraying. Before $\mathrm{MAO}$, the lower sample was ground in a mandrel on a 3B722 surface grinder [16]. Then, the lower sample was subjected to MAO in electrolyte for $120 \mathrm{~min}$. Then the samples were ground on sanding paper to $R a=0.35-0.40 \mu \mathrm{m}$. The upper samples (see Fig. 5) in the amount of three pieces were made of steel 18KhGT (HRC 58-62) with a contact area of $1.5 \mathrm{~cm}^{2}$ and a roughness of the working surface $R a=0.4 \mu \mathrm{m}$.

The reference standard was a friction pair: the lower specimen of an uncoated aluminum alloy and the upper specimen of HRC 58-62 steel. The rotational speed during operation of the rubbing pair was $580 \mathrm{~min}^{-1}$.

The condition of boundary lubrication was ensured by the presence of industrial oil AU GOST 1642-75 in the friction zone (Fig. 6).

After the steady-state constant value of the friction moment and the running-in of the total contact area of the friction pair of at least $90 \%$, the load was increased to the planned experiment $(1.5 \mathrm{MPa})$ at intervals of $0.25 \mathrm{MPa}$.

The value of the wear of the samples and counterbodies was determined by the gravimetric method using a VLA-200 balance according to TU 25.06-383-74.

The wear value was determined every 2 hours of testing with total test duration of each friction pair of 20 hours.

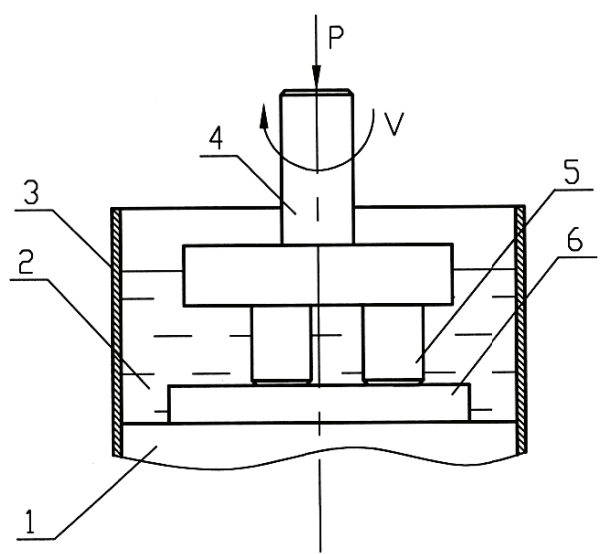

Fig. 6. Sample wear test diagram:

1 - base; 2 - lubricant; 3 - protective casing; 4 - mandrel for upper samples; 5 - upper sample; 6 - bottom sample 


\section{Results and discussion}

In order to select rational operating modes of the equipment, studies of coating adhesion and comparative wear tests were carried out.

The results of the analysis of the adhesion of sprayed coatings obtained on the AK7ch aluminum alloy depending on the air pressure (Fig. 7) showed that the best adhesion of the sprayed material to the base (65 MPa) was achieved when spraying with an air pressure of $0.9 \mathrm{MPa}$. However, given that the installation can operate in this mode only for a short time and is unstable, the most rational is the air pressure of $0.7 \mathrm{MPa}$ in the spraying unit. The adhesion of the sprayed material to the base will be 58-62 MPa.

In the study of adhesion of sprayed coatings, depending on the temperature of air heating in the spraying unit (Fig. 8), it was found that with an increase in temperature, the adhesive strength decreases. This is due to the fact that with an increase in air temperature, the thermodynamic activity of the sprayed particles increases. Consequently, not only particles with sufficient kinetic energy for this will be fixed on the surface, but also particles with lower kinetic energy, but with a higher temperature. This leads to an increase in the effective use of the sprayed material, while reducing the adhesion of the coating. As can be seen from Fig. 8, the maximum adhesion value corresponds to the temperature regime, which provides heating of the air in the spraying unit at about $200^{\circ} \mathrm{C}$. But as studies have shown, at this temperature regime, a low powder utilization rate is observed (4-8\%). With an increase in the temperature of heating the air in the spraying unit to $400{ }^{\circ} \mathrm{C}$, the powder utilization rate

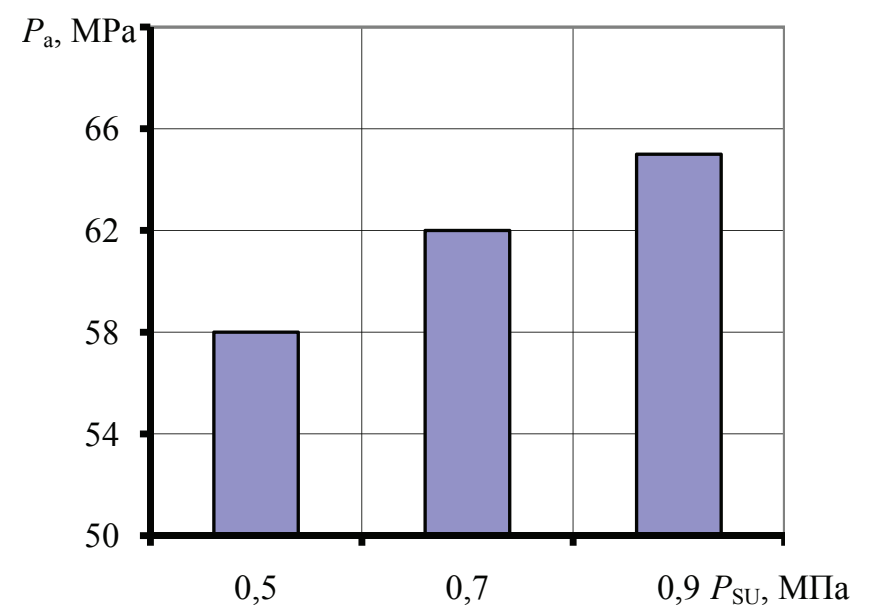

Fig. 7. Correlation between the coating adhesion and the air pressure $\boldsymbol{P}_{\mathrm{SU}}$ in the spraying unit

(Spraying modes: spraying distance $h=15 \mathrm{~mm}$; air heating temperature $T_{\mathrm{SU}}=400{ }^{\circ} \mathrm{C}$; material fraction $f=40 \mu \mathrm{m}$ )

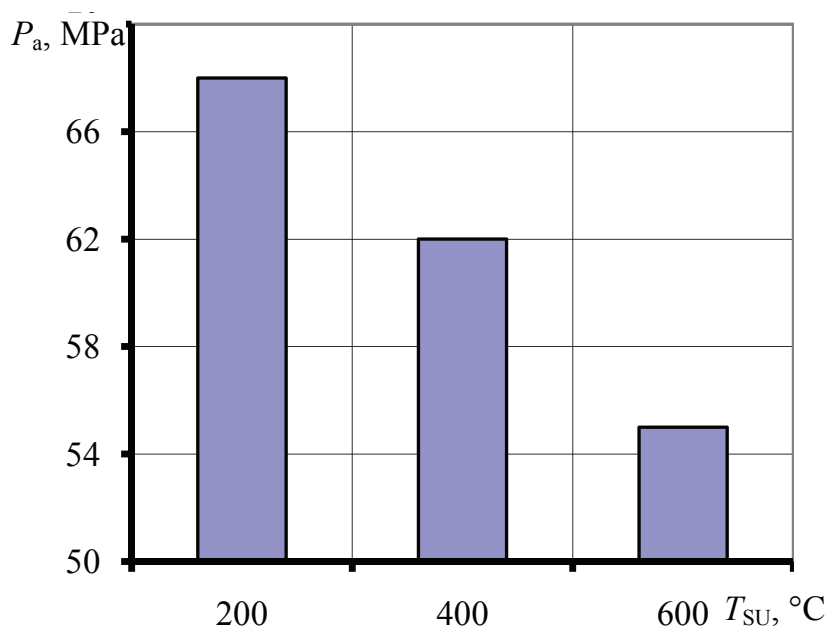

Fig. 8. Correlation between the coating adhesion $\boldsymbol{P}_{\mathrm{a}}$ and the air heating temperature $T_{\mathrm{SU}}$ in the spraying unit

(Spraying modes: air pressure in the sputtering block

$R_{\mathrm{SU}}=0.7 \mathrm{MPa}$; spraying distance $h=15 \mathrm{~mm}$; material fraction $f=40 \mu \mathrm{m})$

reaches $12-15 \%$. Therefore, the optimal temperature regime is the one that provides heating of air in the spraying unit at about $400{ }^{\circ} \mathrm{C}$.

The results of the data (Fig. 9) indicate that the process of interaction of a solid particle with a base, which is realized during gas-dynamic spraying, depends not only on the heating temperature and air pressure in the spraying unit, but also on the size of the sprayed particle, i.e. her factions. For any particle velocity, one can find a size at which it bounces off the substrate, even if the maximum possible number of bonds has formed during the contact.

Thus, the estimate made shows that under the given conditions of interaction of the particle with the base, the elastic compression energy and the adhesion energy have the same values and, therefore, the elastic compression energy plays a decisive role in spraying with solid particles. Therefore, to reduce the effect of elastic rebound of a particle, it is necessary to use sufficiently small $(\approx 40 \mu \mathrm{m})$ particles.

The main parameters of coatings tested for wear are presented in Table 1 .

The wear tests of the compared friction pairs showed (Fig. 10) that wear dependent on the material of the friction pair had different values. The duration of wear testing for friction pairs with lower samples of the following composition is aluminum alloys (AK12, AK7ch, G-AlSi12); aluminum alloy (AK7ch) with a coating formed by GDS (A-80-13 powder); aluminum alloy (AK7ch) with a coating formed by GDS (A-80-13 powder) followed by MAO was 20 hours. 


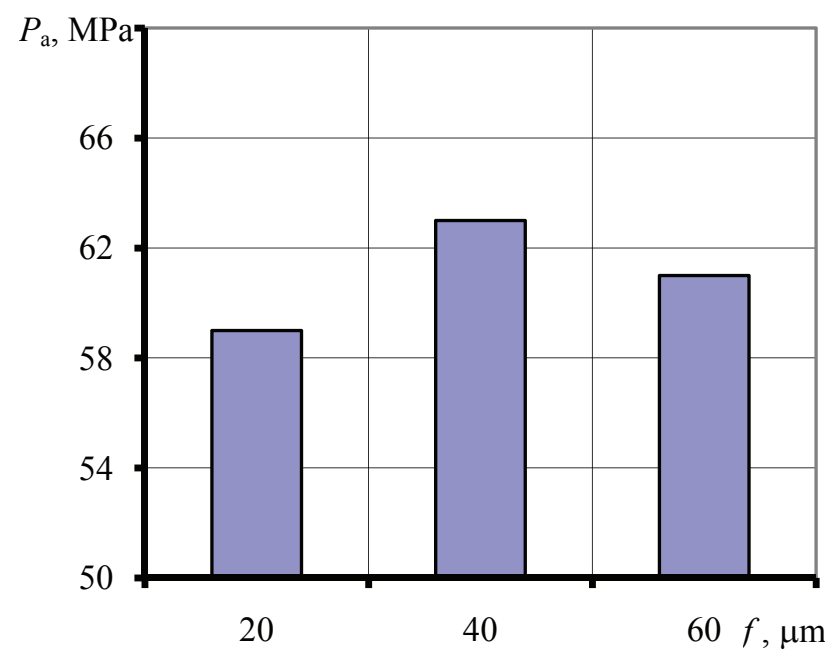

Fig. 9. Correlation between the coating adhesion $\mathbf{P}_{\mathbf{a}}$ andthe fraction of the sprayed material $f$

(Spraying modes: air pressure $P_{\mathrm{SU}}=0.7 \mathrm{MPa}$; spraying distance $h=15 \mathrm{~mm}$; air heating temperature $T_{\mathrm{SU}}=400{ }^{\circ} \mathrm{C}$ )

The wear rate of coatings formed by GDS on aluminum alloys from the A-80-13 powder with subsequent reinforcement by MAO was $0.0062 \mathrm{~g} / \mathrm{h}$. The wear rate of the obtained coating was several times lower than the wear rate of alloys taken as the reference standard: for AK12 alloy - 5.13 times, for AK7ch alloy - 6.41 times, for G-AlSi12 alloy - 5.67 times, for the coating formed by the GDS -7.68 times.
On the basis of the conducted tests, rational modes of spraying and hardening of coatings for GDS and MAO were established (Table 2).

The developed technology includes the following main operations: machining of a part to remove wear marks, abrasive blasting, GDS, boring, MAO, washing, drying, and finishing machining.

The aluminum surfaces of bored shields of electric motors usually do not require special preparation before the GDS spraying. The GDS coating is possible even on surfaces contaminated with oil and paint. However, abrasive blasting (sandblasting) preparation of the surface for spraying increases the adhesion strength of the coating to the substrate. It can be carried out with the help of equipment for GDS, for example,

Table 1

Main parameters of coatings tested for wear

\begin{tabular}{cccc}
\hline Layer thickness, mm & \multicolumn{2}{c}{$\begin{array}{c}\text { Microhardness } \\
\text { of the sprayed layer, MPa }\end{array}$} \\
\hline GDS & $\begin{array}{c}\text { Reinforced } \\
\text { by MAO }\end{array}$ & $\begin{array}{c}\text { Before } \\
\text { MAO }\end{array}$ & After MAO \\
$0.50-0.51$ & $\begin{array}{c}0.130- \\
0.140\end{array}$ & $800-900$ & $9500-10200$ \\
\hline
\end{tabular}

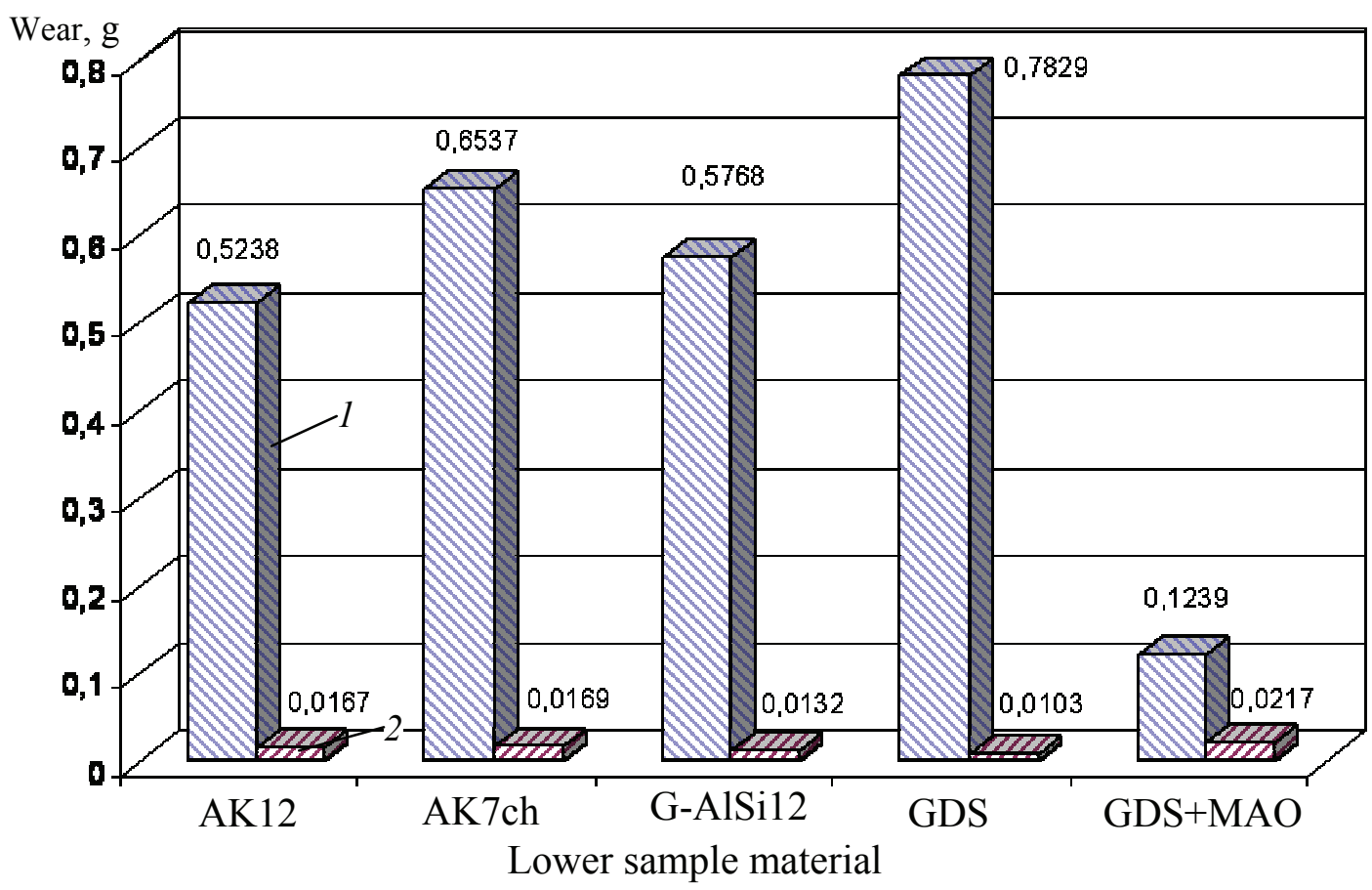

Fig. 10. Wear values of friction pairs:

1 - lower sample wear (aluminum alloys; coating obtained by GDS (A-80-13 powder); coating obtained by GDS (A-80-13 powder) followed by MAO); 2 - upper sample wear (18HGT steel) 
Table 2

Rational modes of coating formation

\begin{tabular}{ccc}
\hline No & \multicolumn{1}{c}{ Parameter } & Value \\
\hline \multicolumn{2}{c}{ Modes of supersonic gas-dynamic spraying of coatings } \\
1 & Compressed air pressure, $\mathrm{MPa}$ & $0.5-0.55$ \\
2 & Compressed air consumption, $\mathrm{m}^{3} / \mathrm{min}$ & $0.3-0.35$ \\
3 & Compressed air heating temperature, ${ }^{\circ} \mathrm{C}$ & $200-450$ \\
4 & Granulation of powder material, microns & $40-60$ \\
5 & Spraying distance, $\mathrm{mm}$ & $5-15$ \\
& Modes of hardening sprayed coatings $M A O$ \\
1 & Current density, A/dm ${ }^{2}$ & $20-25$ \\
2 & Electrolyte temperature, ${ }^{\circ} \mathrm{C}$ & $30-40$ \\
3 & Duration of oxidation, min & $90-120$ \\
\hline
\end{tabular}

K-00-04-16 powder, other abrasive powder or sand. In this case, the particle size of the used powder should not exceed $0.2 \mathrm{~mm}$.

For supersonic gas-dynamic spraying of powder materials on the surface of the mounting holes, DIMET-403 set, mass produced at Obninsk powder spraying center for gas-dynamic spraying is used. It is advisable to use A-80-13 powder as a powder material recommended for the restoration of shields made of aluminum alloys.

It should be noted that the use of GDS allows compensating for the wear of parts up to several millimeters per side $(2-4 \mathrm{~mm})$. In this case, the powder is applied to the surface of the part to be repaired without any sub-layer.

To strengthen the holes restored by gas-dynamic spraying (after their boring on a lathe), a set of equipment for micro-arc oxidation $01.08-05$ is used. With MAO, it is advisable to use an alkaline electrolyte with additions of water glass, with the following concentration of components, $\mathrm{g} / \mathrm{l}$ : potassium hydroxide $(\mathrm{KOH})-2.9-3 \mathrm{~g} / \mathrm{l}$; liquid glass $\left(\mathrm{Na}_{2} \mathrm{SiO}_{3}\right)-4-6 \mathrm{~g} / \mathrm{l}$.

Due to the fact that MAO provides the formation of a hardened layer not only inside the part, but also outward and increases its linear dimensions (an outer loose layer is formed), the shields must be reinforced taking into account the allowance for finishing machining (at least $0.05-0.07 \mathrm{~mm}$ per side).

To remove the outer loose layer of the coating after MAO (finishing machining), it is recommended to use an elastic abrasive tool consisting of abrasive paper petals fixed between two discs. After finishing

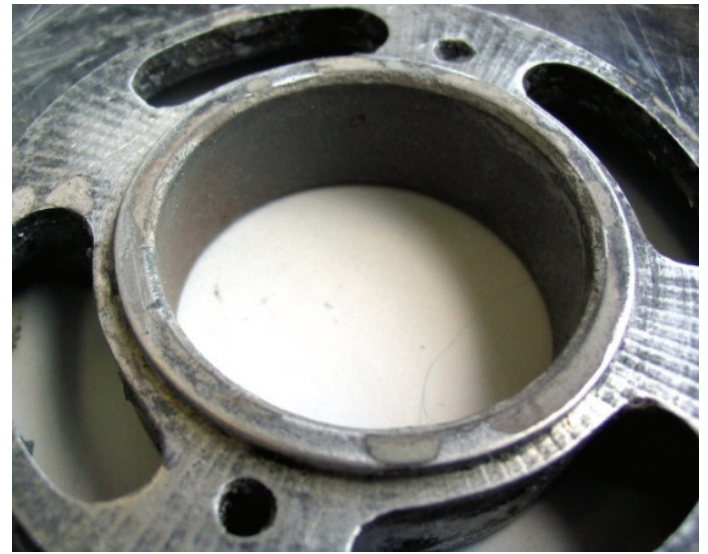

Fig. 11. Bearing shield of the AD type electric motor with coating

machining of the coating, the thickness of the hardened layer should be at least $0.12-0.14 \mathrm{~mm}$.

The general view of the restored bearing assembly of the electric motor is shown in Fig. 11.

\section{Conclusion}

Based on the studies carried out, it can be assumed that the service life of the bearing unit of an electric motor restored by the GDS combined with a new technology of MAO in real operating conditions will increase by an average of 3-4 times. The developed technology is recommended for implementation at repair and technical and other technical service enterprises engaged in the restoration and hardening of worn parts.

\section{References}

1. Alkhimov A.P., Klinkov S.V., Kosarev V.F., Fomin V.M. Kholodnoye gazodinamicheskoye napyleniye [Cold gas-dynamic spraying]. Novosibirsk: Fizmatlit, 2010. 536 p. (Rus)

2. Cavaliere, P. Cold-Spray Coatings, Recent Trends and Future Perspectives; Cavaliere, P., Ed.; Springer International Publishing AG: Cham, Switzerland, 2018.

3. Kuznetsov YU.A., Kravchenko I.N. Issledovaniye mekhanizma vzaimodeystviya chastits $s$ metallicheskoy podlozhkoy pri sverkhzvukovom gazodinamicheskom napylenii [Investigation of the mechanism of interaction of particles with a metal substrate in supersonic gas-dynamic spraying]. In Vse materialy. Entsiklopedicheskiy spravochnik. 2019, 8, 18-24. (Rus)

4. Kuznetsov Yu.A., Kravchenko I.N. A study of the mechanism of interaction between particlesand 
metal substrate at supersonic gas dynamic cold spraying. Polymer Science. Series D. 2020, 13(1), 89-94.

5. Lee H.Y., Yu Y.H., Lee Y.C., Hong Y.P., Ko K.H., Thin Film Coatings of WO3 by Cold Gas Dynamic Spray: A Technical Note. J. Therm. Spray Technol. 2005, 14, 183-186.

6. Avvakumov M.Ye., Rufitskiy M.V. Nadezhnost' $i$ kachestvo pokrytiya pri ispol'zovanii metoda "kholodnogo" gazodinamicheskogo napyleniya [Reliability and quality of the coating when using the method of "cold" gas-dynamic spraying.]. Trudy Mezhdunarodnogo simpoziuma "Nadezhnost' $i$ kachestvo”. 2013, 2, 112-113. (Rus)

7. Suminov I.V., Epel'fel'd A.V., Lyudin V.B. et al. Mikrodugovoye oksidirovaniye (teoriya, tekhnologiya, oborudovaniye) [Microarc oxidation (theory, technology, equipment)]. M.: EKOMET, 2005. 368 p. (Rus)

8. Tihonenko V.V., Shkilko A.M. Method of micro-arc oxidation. East European Journal of advanced technology. 2012, Vol. 2, 13 (56), 13-18.

9. Lei Wen, Yaming Wang, Ying Jin, Bing Liu, Yu Zhou, Dongbai Sun. Microarc oxidation of 2024 Al alloyusing spraying polar and its influence on microstructure and corrosion behav-ior. Surface \& Coatings Technology. 2013, 228, 92-99.

10. Tran Q.-P., Kuo Y.-C., Sun J.-K., He J.-L., Chin T.-S. High quality oxide-layers on Al-alloy by micro-arc oxidation using hybrid voltages. Surf. Coat. Technol. 2016, 303, 61-67.

11. Kuznetsov Yu.A., Kravchenko I.N., Goncharenko V.V., Glinskii M.A. Machining of the ceramic oxide coating formed by plasma electrolytic oxidation. Russian metallurgy (Metally). 2018, 13, 82-86.

12. Kuznetsov Yu.A. Combined technology of production of ceramic coatings. Welding International. 2005. 19(11), 894-896.

13. Kuznetsov Yu.A., Kolomeichenko A.V., Goncha-renko V.V., Kravchenko I.N. Investigation of internal stresses in thin layer oxide coatings on aluminum alloys. Materials Science Forum, 2019, 968, 153-160, doi.org/10.4028/www.scientific.net/ MSF.968.153

14. Kuznetsov Yu.A., Markov M.A., Krasikov A.V., Bystrov R.Yu., Belyakov A.N., Bykova A.D., Makarov A.M., Fadin Yu.A. Formation of wear-and corrosion-resistant ceramic coatings by combined technologies of spraying and micro-arc oxidation. Russian Journal of Applied Chemistry. 2019, 92(7), 875-882.

15. Chernyshov N.S. Vnutrenniye napryazheniya $v$ detalyakh iz alyuminiyevogo splava AK9ch vosstanovlennykh paykoy $s$ ispol'zovaniyem pripoya PA-12 [Internal stresses in parts made of AK9ch aluminum alloy recovered by soldering using PA-12 solder]. Agrotekhnika $i$ energoobespecheniye 2014, 1(1), 155-159. (Rus)

16. Kuznetsov YU.A., Mityureva N.V. Shlifovaniye detaley iz alyuminiyevykh splavov, uprochnennykh mikrodugovym oksidirovaniyem [Grinding of parts made of aluminum alloys hardened by micro-arc oxidation]. Uprochnyayushchiye tekhnologii i pokrytiya. 2010, 2, 38-40. (Rus) 